\title{
Is Emotional Intelligence an essential element in global learning environment to become socially responsible innovators?
}

\author{
Cittoor Girija Navaneedhan \\ Senior Fellow, ICSSR, Department of Management Studies \\ IIT, Madras, India \\ girija.navaneedhan@gmail.com
}

TJ Kamalanabhan

Department of Management Studies IIT, Madras, India.

tjk@iitm.ac.in

\begin{abstract}
Emotional intelligence in its basic sense is defined as the term representing the ability of an individual to understand his/her own emotions as well as others. 21st century is considered globally as knowledge-based society by eminent scholars, policy makers, stake holders etc, the question still remains unanswered is 1 . Have we achieved $100 \%$ literacy rate globally? 2. Is there a sustainable development in global Economy? 3. Is there an Economic and Social narrow down between developed and developing nations of the world in terms of Education, Health, Industrialization? The inventions in 20th century contributed to a large extent providing material comfort to both developed and developing nations without addressing the emotional well-being of its citizens the core constituents of human capital. Therefore, the present-day global learning environment is expected to refine the emotional intelligence trait of teachers, the key players in shaping the society to a well-equipped emotionally successful global innovator.
\end{abstract}

Keywords. Emotional Intelligence, human capitol, global learning, sustainable development

\section{Introduction}

In order to equip the society with emotionally successful global innovators, it necessary to consider the four dimensions of emotional intelligence namely: a) the cognitive ability b) tolerance c) ego and d) decision making. The present paperwork examines how these four dimensions has impact on emotional intelligence of an individual.

The role of cognitive ability on emotional intelligence

Mayor and Salovey (1997), research mentioned that in recent years emotional intelligence and cognition are complementary aspects of individual's psyche that they are not separable for the reason that they together determine the performance of all the activities in everyday life. An emotionally stable individual possesses the cognitive ability to perceive the environment through the senses accurately, appraise, and express emotion; the ability to 
access and/or generate feelings, which in turn facilitate thought process ultimately developing the ability to understand emotion and emotional knowledge; and the ability to regulate emotions to promote emotional and intellectual growth. Joseph and Newman (2010), Joseph et al (2015). reported EI as a measure of the individual's ability in work success, wellbeing, decision making and stress management. In recent years researchers Gutierrez- Cobo et al(2017),study focused on how EI impacts on cognitive ability while performing hot and cold tasks. Hot task is the commonly used Iowa gambling task (Becharra et al 1994, Kerr and zalazo 2004). The cold task is by Flanker (Eriksen and Eriksen 1774). Webb et al (2014) suggested that EI is related to cognitive control only when the cognitive task has an emotional aspect and when EI is evaluated within performance-based ability models the aim of this study was to examine whether cognitive control implemented for persons high or low on EI. Purifaccion et al (2019) hypothesised in their study that EI is directly related to cognitive ability in hot task compared to cool task. Bar On et al (2003), viewed the relationship between EI and cognitive ability as individual's ability to carefully respond or react to the present situation and to sustain it on a long term. Daniel Goleman (1995), quoted in his book that people with a higher Emotional Quotient (EQ) report fewer physical ailments, less anxiety and depression, and greater use of active coping strategies for problem-solving. Emotionally intelligent people recognize their strengths and weaknesses, know how to manage stress, can work well with others, are socially aware and develop strategies to help them reach their goals in life, all of which contribute to greater levels of happiness. A.Megias et al (2017) conducted a neurobiological study to find the relationship between EI and cognitive ability by performing an emotional go/no go task on two groups of 22 participants with low and high EI by recording their brain activity using EEG technique measuring ERP values between the frontal and central regions of the brain, Participants with higher EI showed a larger amplitude deflections reflecting a greater capacity for cognitive control related to changes in conflict monitoring, and to a better detection and evaluation of the emotional stimuli. Importantly the above study showed a strong evidence that EI and cognitive ability are strongly related. Emotional intelligence arises from cognition and emotion and eventually it facilitates our capacity for resilience, motivation, empathy, reasoning, stress management, communication, and the ability to read and navigate a plethora of social situations and conflicts in individuals. Therefore, EI matters and if cultivated affords one the opportunity to realize a more fulfilled and happy life.

\section{The role of Decision making in Emotional Intelligence}

Several research studies have shown that EI influences the decision-making ability of the individuals. For example, individual's with low emotional intelligence are poor in decision making as their anxiety influences decision making compared to people with high emotional intelligence anxiety is blocked showing null influence on decision-making George (2000) in his article "Emotion and Leadership" based on two preliminary studies recommend that leaders' feelings may play an important role in leadership. In these two studies, George and Bettenhausen (1990) point out, that if the leaders of existing work groups experienced positive moods which in turn is positively related to the levels of pro-social behaviour performed by group members and negatively related to group turnover rates. In addition, George (1995) found that if the work groups led by sales managers who tend to experience positive moods at work provided higher quality customer service than groups led by managers who did not tend to experience positive moods at work. However, neurological studies by Damasio and others have demonstrated that people who lack the potential of emotional response often make poor decisions that can critically limit their functioning in society (Damasio, 1994). Professor Cote 
of Toroto University quoted that "people who are Emotionally Intelligent do not remove all emotions from their decision making. They remove emotions that have nothing to do with the decision." Francesca Gino a Harvard Business school Professor suggested that when an individual is influenced by highly positive or negative emotional feeling, a self-introspection is necessary to find about the decision taken is under the influence social or organisational pressure. Under such circumstances, Gino recommends that the individual to take a short break from the situation to process the information to identify his/her emotional state that could have saved them from making decision which They might repent later. (Goleman, 2001; Boyatzis et al., 2000) viewed that decision makers have freedom to utilize self-Management skills to establish themselves a continuous achievement and emotional control simultaneously earning them trust from both internal and external constituencies in an organization. Emotionally Intelligent person makes appropriate decision in a given situation as he/she capable of managing emotion

$>$ To improve the situation,

$>$ To view things clearly when feelings are overpowering

$>$ To make good, solid decision even when angry

$>$ Not to react out of anger

$>$ To balance their thoughts and their feelings

$>$ Not to let strong emotions blind them

Based on several research studies it is ascertained that EI is extremely important in decision making. Hence consciously improving EI through self-introspection, individuals can master the skill of decision making.

\section{The role of Ego in Emotional Intelligence}

The Psychological meaning of Ego is one of the three "Functions" of human mind. The other two being "Id" and "Super Ego". In this context the term "Ego" refers to a personality trait of an individual having the ability to satisfy his/herself at the expense of others. Eric Bern (1950) nearly seven decades ago mentioned in his transactional analysis theory that every individual has inbuilt ego states of a parent, a adult and a child. As these three states are associated with their own thoughts feelings and behaviours it is possible to understand to which state of ego the behavioural outcome determines. He further states that the individual's behaviour in these states decided by nurturing by a parent. The ego state of a parent is quite different from the ego state of adult and a child due to the reason that parent ego state results own experiences, information, personal process and previous experiences. Whereas, ego state of the adult is in still developing state hence, while handling with adult who constitute most of the work force it is necessary to keep in mind the three ego states and act accordingly. Therefore, in many instances it has been proved beyond doubt that successful leaders are those who tackle the adulthood ego states of their work force convincingly. A study by Kristine Gill Belarmino (2018) showed that a teacher with a high level of emotional intelligence, he/she can regulate one's emotion and to cope with different stressors and adversity. As they can regulate their emotions, they will be able to manage themselves when faced with future adversities. Several studies have established that the Emotional intelligence contribute a lot to mental well-being of the individuals, the present study deals with the emotional intelligence of teachers is essential for their well-being, effectiveness, and quality in carrying out teaching learning processes in the classroom in general, and for managing the emotions of their students as well. A teacher who can manage his or her emotions and feelings is very effective and competent in terms of teaching as he or she also adopts innovative 
attitude, flexible teaching methods in his or her approach, always reflecting on with day-today developments in different subject area. At the same time, capable of recognizing the value of human potentials, understanding the diverse needs of learners and enriching the environment for its own growth. Teachers are expected take control over students in a healthy manner since classroom situations are not predictable at times due to different behaviours of the students. This situation can be handled by the teachers with high emotional intelligence. Another important factor is teachers are not expected to be egoistic. High emotional intelligence with less ego is very important factor to be considered in teaching- learning process as well as in class-room management. Emotions play an important role to complete our cognitive abilities and are and has become an integral part of decision making. Emotional intelligence is the ability to recognize, express, assimilate emotions in thought, understand and reason with emotion and regulate emotion in the self. Moreover, ego is the ability to adapt one's level of control temporarily up or down as circumstances dictate. In addition to emotional intelligence, it is a positive characteristic that means having a positive emotion that involves the ability to monitor one's own and others' feelings and emotions, to discriminate among them and to use this information to guide one's thinking and actions Salovey, P. \& Mayer, J. D, (1990). People with low ego trait can take correct choices at the time destress and also reflect high emotional intelligence.

\section{Role of Tolerance in Emotional Intelligence}

Tolerance is considered as another important dimension of emotional intelligence as it is needed to handle and influence other people's emotions effectively to manage interactions successfully. These abilities range from being able to tune into another person's feelings and understand how they feel and think about things. According to Sternberg R.J (1997) tolerance dimension of emotional intelligence enables the individual to be a great collaborator and team player, to expertise at emotions of others and at negotiations. It is all about the ability to get the best out of others, to inspire and to influence them, to communicate and to build bonds with them, and to help them change, grow, develop, and resolve conflict. Developing the sense of tolerance is considered the most acclaimed state of emotional intelligence as it imparts the ability to accept and control your emotions and emotional reactions as well as those of other people. It helps an individual to learn about his/her own self and move on to the understanding of another people's self. Therefore, an individual learns to coexist better, which is very important since all of us live in a society not alone. Hence, there must be cooperation and harmony. With emotional intelligence, people learn to insist, to control own impulses, to survive despite adversities and difficulties, to hope for and to have empathy. Faltas (2017) proposed emotional intelligence model consisting of 15 dimensions namely: self-regard, self-actualization, emotional self-awareness, emotional expression, assertiveness, independence, interpersonal relationships, empathy, social responsibility, problem-solving, reality testing, impulse control, flexibility, stress tolerance and optimism. The present study emphasises on tolerance as an important dimension that $21^{\text {st }}$ century teachers should possess to reflect on their students to become global innovators. Goleman (2002) pointed out that a leader, in this context the teacher, who practices praise or criticism at equal length, neither supports nor guides, encourages flexibility and allow pupil free rein to do their best is considered as role model, from whom pupil take their emotional cues. Therefore, tolerance trait must be passed on from teachers to learners. 


\section{Methodology}

Research study is carried out by survey method. The sample for the study is carried out by stratified sampling method consisting of 379 teachers (Male and Female) in the age group ranging from 25 to 55 years working in Govt and private schools at Chennai, Tamil Nadu, India. A questionnaire evaluating EI based on four dimensions namely: Cognitive ability, Tolerance, Ego and Decision making each consisting of 15 statements. Each statement is evaluated based on 6-point Likert scale range from not at all $=0$, once in a while $=1$, sometimes $=2$, fairly often $=3$, frequently $=4$, always $=5$. Factor analysis as well as the reliability of the questionnaire was carried out. Cronbach's alpha is calculated using split-half method is given the value $=0.708$. The standardised questionnaire is distributed to the teachers and are instructed to read each and every statement carefully and tick the appropriate option. The questionnaires thus collected with appropriate responses are subjected statistical analysis to meet the objectives and answer the research questions.

\section{Objectives of the study}

$>$ To find out the significant differences between male and female population of the sample with respect to Emotional Intelligence.

$>$ To find out inter relationship between the four dimensions of EI as stated in the questionnaire.

$>$ To evaluate regression model based on four dimensions of EI.

$>$

\section{Research Questions}

$>$ Is there a significant difference between male and female population of the sample with regard to four dimensions of the questionnaire quantifying EI?

$>$ Is there interrelationship between the four dimensions of the questionnaire quantifying EI?

$>$ How do these four dimensions of the questionnaire together represent a regression model in quantifying EI?

\section{Analysis of the data}

The data collected from 379 teachers are analysed using SPSS software version 24. Six hypotheses are formulated to test their validity as well as to answer the research questions. Hypotheses 1: There is no significant difference among male and female sample with respect to Cognitive ability, Tolerance, Ego and Decision-making dimensions of Emotional Intelligence

Table 1: To show the significant difference between male and female population with reference to Psychological variables.

\begin{tabular}{|c|c|c|c|c|c|c|}
\hline $\begin{array}{l}\text { Psychological } \\
\text { variable }\end{array}$ & $\begin{array}{c}\text { Male } \\
\mathrm{N}\end{array}$ & $\begin{array}{l}\text { Female } \\
\mathrm{N}\end{array}$ & Mean & S. D & $\begin{array}{l}\text { Test of } \\
\text { significance } \\
\text { "t"" }\end{array}$ & $\begin{array}{l}\text { Level of } \\
\text { significance }\end{array}$ \\
\hline \multirow{2}{*}{$\begin{array}{l}\text { Cognitive } \\
\text { ability }\end{array}$} & \multirow{6}{*}{87} & \multirow{6}{*}{292} & 42.52 & 8.84 & \multirow[t]{2}{*}{1.014} & \multirow[t]{2}{*}{ N. S } \\
\hline & & & 41.44 & 8.15 & & \\
\hline \multirow[t]{2}{*}{ Tolerance } & & & 45.39 & 6.91 & \multirow[t]{2}{*}{2.19} & \multirow[t]{2}{*}{0.03} \\
\hline & & & 43.42 & 8.71 & & \\
\hline \multirow[t]{2}{*}{ Ego } & & & 39.55 & 9.86 & \multirow[t]{2}{*}{0.23} & \multirow[t]{2}{*}{ N. S } \\
\hline & & & 39.27 & 9.27 & & \\
\hline
\end{tabular}




\begin{tabular}{|l|l|l|l|l|l|l|}
\hline Decision & \multirow{2}{*}{$\begin{array}{l}\text { Making } \\
\end{array}$} & & 46.06 & 9.07 & 0.12 & \multirow{2}{*}{ N. S } \\
\cline { 3 - 4 } & & 45.92 & 9.09 & & \\
\hline
\end{tabular}

${ }^{*} \mathrm{p}<0.5, * * \mathrm{p}<0.01, * * * \mathrm{p}<0.001, \mathrm{~N} . \mathrm{S}=$ Not significant

From the table 1 it is shown that male and female population of the sample vary significantly in Tolerance dimension of EI. In the case cognitive ability, ego and decision making there is no significant difference indicating that gender has no role to play in EI. The result is in consistent with the study conducted by Maryam Meshkat, Reza Nejati (2017).

Hypotheses 2: Cognitive ability of an individual is not determined by Tolerance, Ego and Decision making of the sample in quantifying EI

Table 2: To show the effect of determinants tolerance ego and decision making on cognitive ability

\begin{tabular}{|c|c|c|c|c|c|c|c|c|c|}
\hline Variable & $\mathrm{N}$ & Mean & S. D & $\begin{array}{l}\text { Pearson } \\
\text { correlat } \\
\text { ion "r" }\end{array}$ & $\begin{array}{l}\text { Regre } \\
\text { ssion } \\
\text { R }\end{array}$ & " $t "$ & $\mathrm{~F}$ & Beta & $\begin{array}{l}\text { Level of } \\
\text { significance }\end{array}$ \\
\hline $\begin{array}{l}\text { Cognitive } \\
\text { ability }\end{array}$ & 379 & 41.69 & 8.31 & 1.00 & \multirow[t]{4}{*}{0.51} & 6.66 & \multirow[t]{4}{*}{43.09} & & \multirow[t]{4}{*}{$<0.05$} \\
\hline Tolerance & 379 & 43.88 & 8.37 & 0.383 & & 4.43 & & 0.223 & \\
\hline Ego & 379 & 39.34 & 9.40 & 0.310 & & 1.29 & & 0.067 & \\
\hline $\begin{array}{l}\text { Decision } \\
\text { Making }\end{array}$ & 379 & 45.96 & 9.08 & 0.452 & & 6.35 & & 0.331 & \\
\hline
\end{tabular}

$\mathrm{S} * \mathrm{p}<0.5, * * \mathrm{p}<0.01, * * * \mathrm{p}<0.001, \mathrm{~N} . \mathrm{S}=$ Not significant

Scatter plot showing the dependence of the cognitive ability dimension on the predicted variables: tolerance, ego and decision making

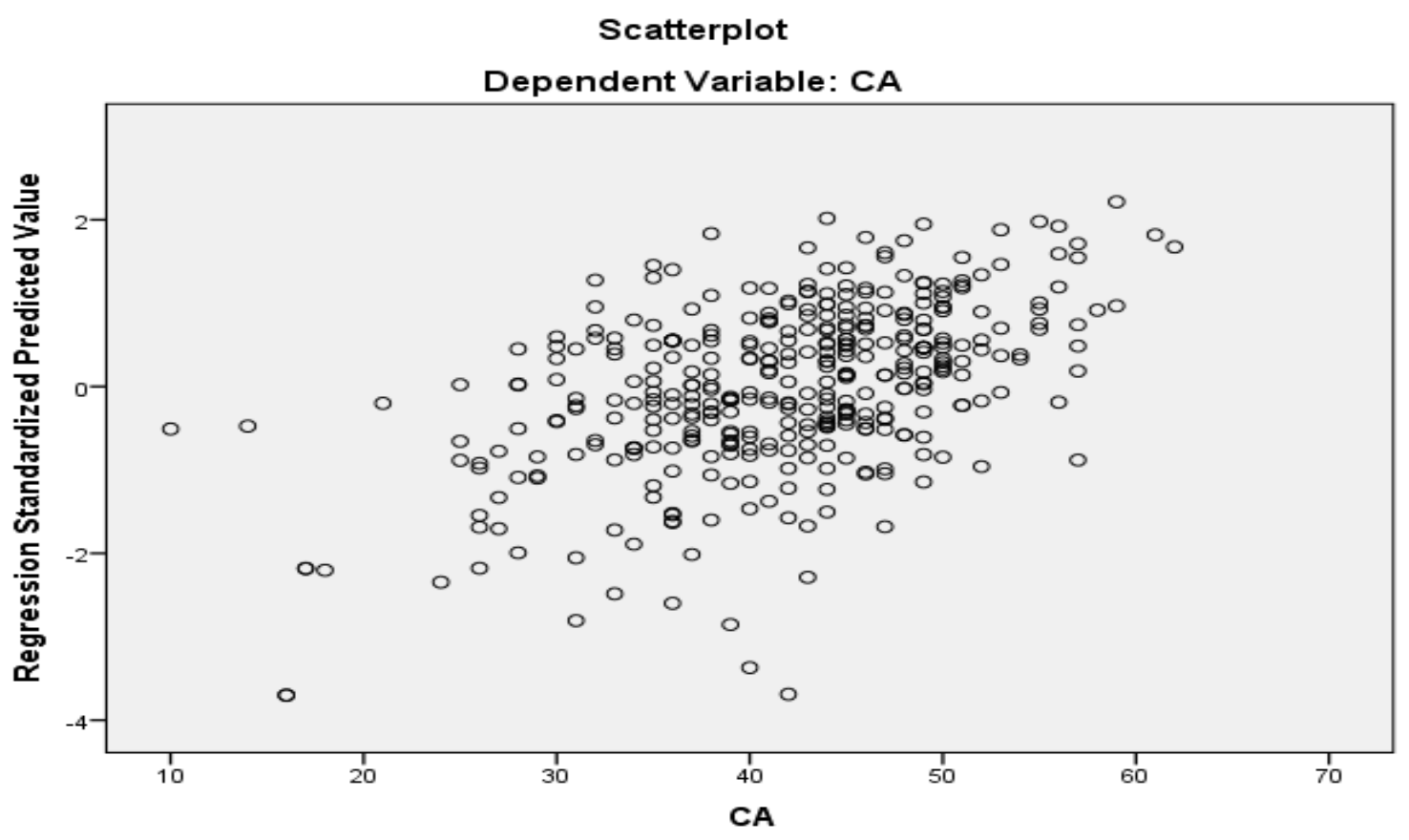

Figure 1: Plot showing the relationship between Cognitive ability with three predictors 
The results of the table 2 and the scatter plot shows that the Regression value significant meaning that the cognitive ability dimension of EI is determined by the three predicted variables to the extent of $51 \%$ rejecting the hypotheses and accepting the alternate hypotheses. Therefore, the variables are significantly related to one another to determine the EI of the sample, Regression is carried out with Tolerance as dependent variable and cognitive ability, ego and decision making as predicted variables.

Hypotheses 3: Tolerance of an individual is not determined by cognitive ability, ego and decision making in quantifying EI

Table 3 To show the effect of the determinants cognitive ability ego and decision making on tolerance

\begin{tabular}{|c|c|c|c|c|c|c|c|c|c|}
\hline Variable & $\mathrm{N}$ & Mean & S. D & $\begin{array}{l}\text { Pearson } \\
\text { correlat } \\
\text { ion "r" }\end{array}$ & $\begin{array}{c}\text { Regre } \\
\text { ssion } \\
\text { R }\end{array}$ & " $t$ '" & $\mathrm{F}$ & Beta & $\begin{array}{l}\text { Level of } \\
\text { significance }\end{array}$ \\
\hline Tolerance & 379 & 43.88 & 8.37 & 1.00 & \multirow{4}{*}{0.508} & 7.78 & \multirow{4}{*}{43.42} & & \multirow{4}{*}{$<0.05$} \\
\hline $\begin{array}{l}\text { Cognitive } \\
\text { ability }\end{array}$ & 379 & 41.69 & 8.31 & 0.383 & & 4.43 & & 0.223 & \\
\hline Ego & 379 & 39.34 & 9.40 & 0.398 & & 4.77 & & 0.241 & \\
\hline $\begin{array}{l}\text { Decision } \\
\text { Making }\end{array}$ & 379 & 45.96 & 9.08 & 0.402 & & 3.51 & & 0.189 & \\
\hline
\end{tabular}

${ }^{*} \mathrm{p}<0.5,{ }^{* *} \mathrm{p}<0.01, * * * \mathrm{p}<0.001, \mathrm{~N} . \mathrm{S}=$ Not significant

From table 3 , it is shown that the predictor variables namely cognitive ability, ego and decision making determine the dependent variable tolerance to the extent of $50 \%$ indicating the interdependence meaning that the quantification of EI very depends on tolerance, ego, decision making as well as cognitive ability. The same is observed form the scatter plot also, the regression standardised predictor variables are linearly related to tolerance.

Figure2: Plot showing the relationship between Tolerance with predicted variables 


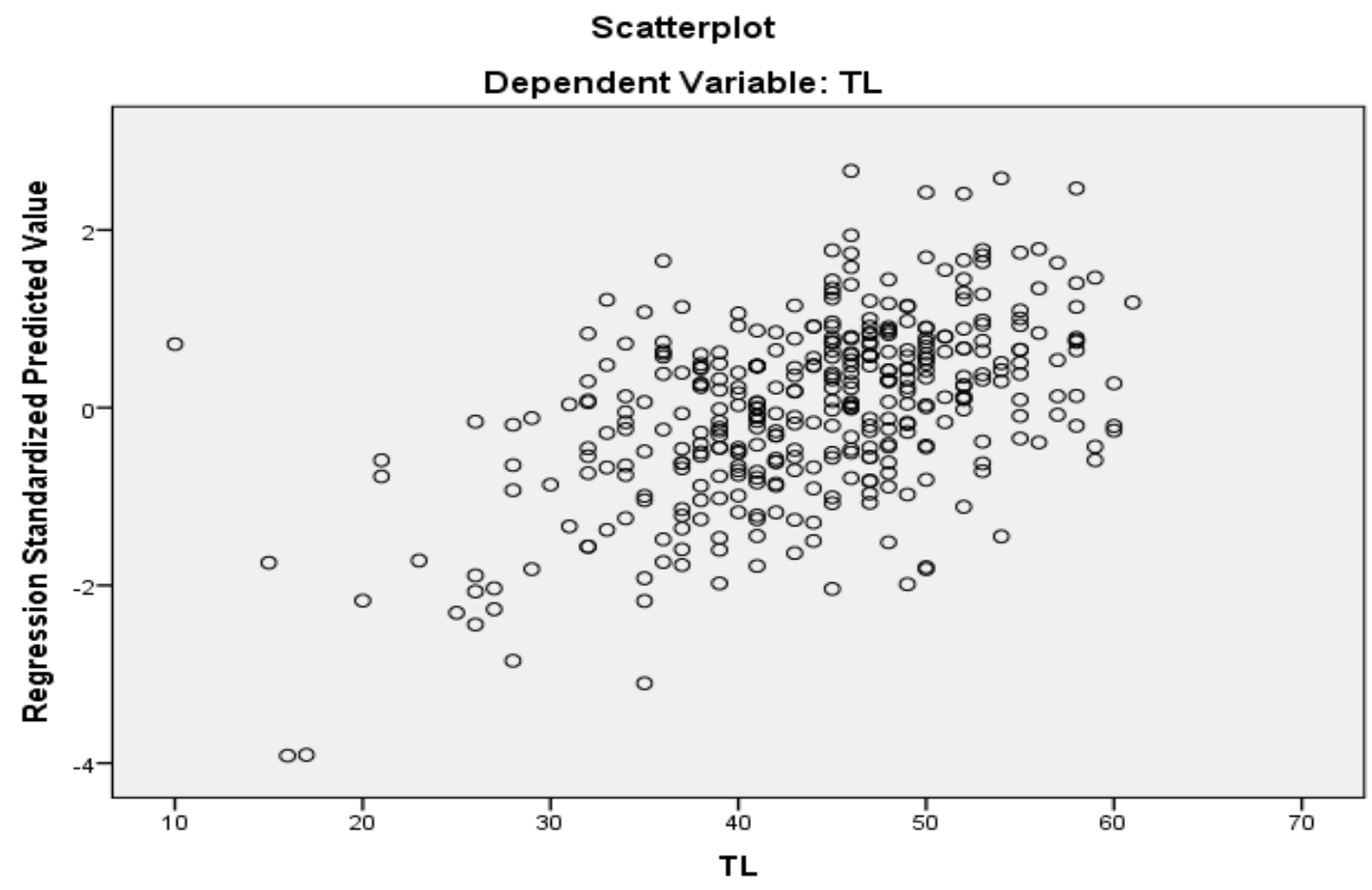

Hypotheses 4: Ego of an individual is not determined by cognitive ability, tolerance and decision making in quantifying EI.

Table 4: To show the effect of the determinant variables: cognitive ability, tolerance and decision making on ego

\begin{tabular}{|c|c|c|c|c|c|c|c|c|c|}
\hline Variable & $\mathrm{N}$ & Mean & S. D & $\begin{array}{l}\text { Pearson } \\
\text { correlat } \\
\text { ion "r" }\end{array}$ & $\begin{array}{l}\text { Regres } \\
\text { sion } \\
\text { R }\end{array}$ & "tt" & $\mathrm{F}$ & Beta & $\begin{array}{l}\text { Level of } \\
\text { significance }\end{array}$ \\
\hline Ego & 379 & 39.34 & 9.40 & 1.00 & \multirow[t]{4}{*}{0.522} & 3.07 & \multirow[t]{4}{*}{46.70} & & \multirow[t]{4}{*}{$<0.05$} \\
\hline $\begin{array}{l}\text { Cognitive } \\
\text { ability }\end{array}$ & 379 & 41.69 & 8.31 & 0.310 & & 1.29 & & 0.066 & \\
\hline Tolerance & 379 & 43.88 & 8.37 & 0.398 & & 4.77 & & 0.237 & \\
\hline $\begin{array}{l}\text { Decision } \\
\text { Making }\end{array}$ & 379 & 45.96 & 9.08 & 0.464 & & 6.59 & & 0.339 & \\
\hline
\end{tabular}

${ }^{*} \mathrm{p}<0.5, * * \mathrm{p}<0.01, * * * \mathrm{p}<0.001, \mathrm{~N} . \mathrm{S}=$ Not significant 
From table 4 It is shown that the regression value is significant indicating that the predictors cognitive ability, tolerance and decision making together account for the ego dimension of EI, individual prediction differs for example the dependence of cognitive ability with ego is only $6.6 \%$, tolerance on ego is $24 \%$ whereas decision making on ego is $34 \%$. Together all the three are good predictors of ego.

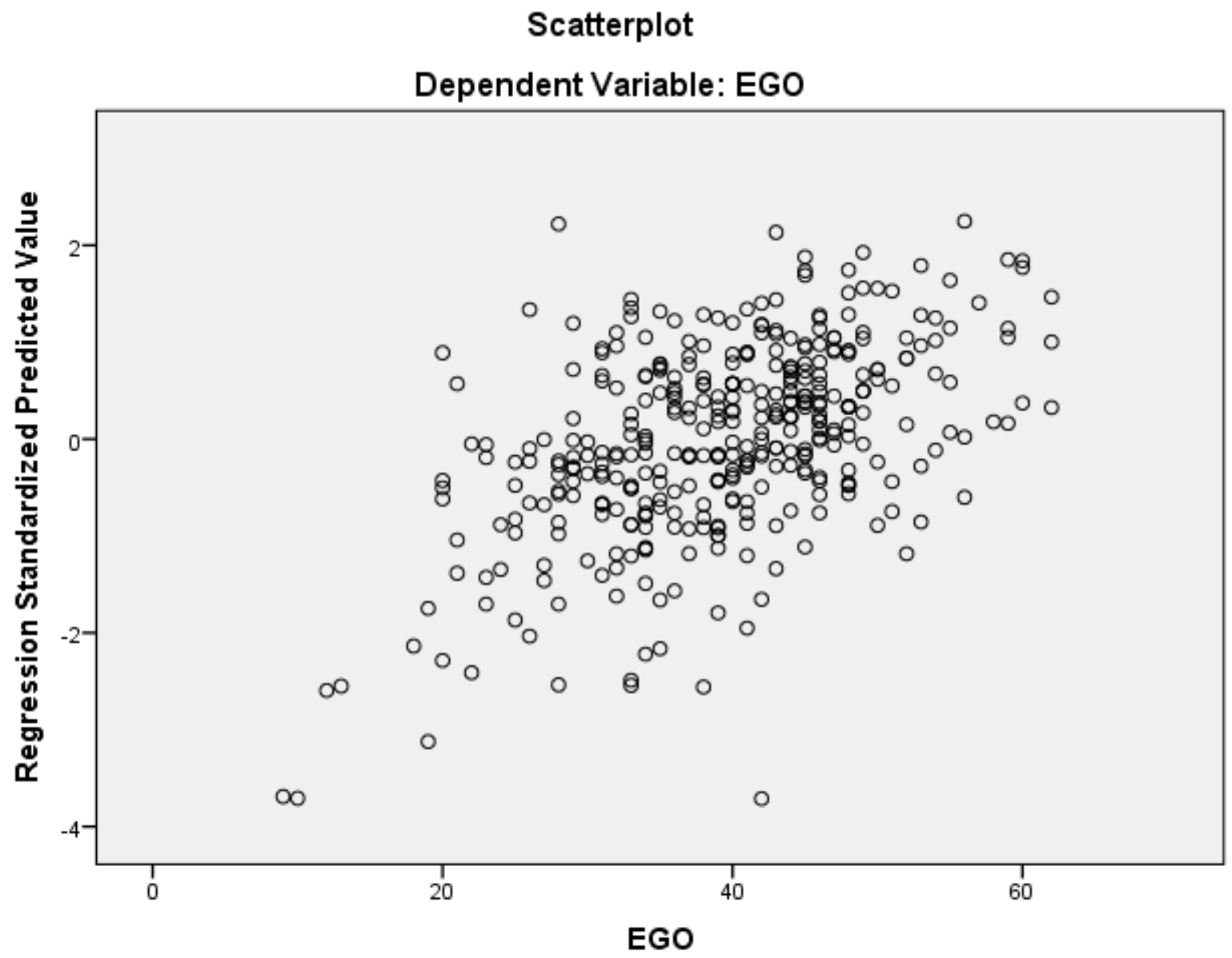

Figure 3: Shows the linear variation of Ego with Cognitive ability, Tolerance and Decision making.

Hypotheses 5: Decision making of an individual is not determined by cognitive ability, tolerance and ego in quantifying EI.

Table 5 shows the Regression value calculated showing the dependence of decisionmaking dimension of EI on Cognitive ability, Tolerance and Ego. The "R" value is shown as 0.585 indicating that the predictors cognitive ability, tolerance and ego determine decision making dimension of EI. Therefore, regression values calculated shows that all the four dimensions measured in this study truly quantify EI of an individual. 
Table 5: To show the dependence of decision making on the predictors ego, tolerance and cognitive ability of the sample.

\begin{tabular}{|c|c|c|c|c|c|c|c|c|c|}
\hline Variable & $\mathrm{N}$ & Mean & S. D & $\begin{array}{l}\text { Pearson } \\
\text { correlat } \\
\text { ion "r" }\end{array}$ & $\begin{array}{l}\text { Regre } \\
\text { ssion } \\
\text { R }\end{array}$ & "'t" & $\mathrm{F}$ & Beta & $\begin{array}{l}\text { Level of } \\
\text { significance }\end{array}$ \\
\hline $\begin{array}{l}\text { Decision } \\
\text { making }\end{array}$ & 379 & 45.96 & 9.08 & 1.00 & \multirow{4}{*}{0.585} & 5.27 & \multirow[t]{4}{*}{65.00} & & \multirow[t]{4}{*}{$<0.05$} \\
\hline Ego & 379 & 39.34 & 9.40 & 0.464 & & 6.59 & & 0.306 & \\
\hline Tolerance & 379 & 43.88 & 8.37 & 0.402 & & 3.51 & & 0.168 & \\
\hline $\begin{array}{l}\text { Cognitive } \\
\text { ability }\end{array}$ & 379 & 41.69 & 8.31 & 0.452 & & 6.35 & & 0.293 & \\
\hline
\end{tabular}

${ }^{*} \mathrm{p}<0.5, * * \mathrm{p}<0.01, * * * \mathrm{p}<0.001, \mathrm{~N} . \mathrm{S}=$ Not significant

\section{Scatterplot}

\section{Dependent Variable: DM}

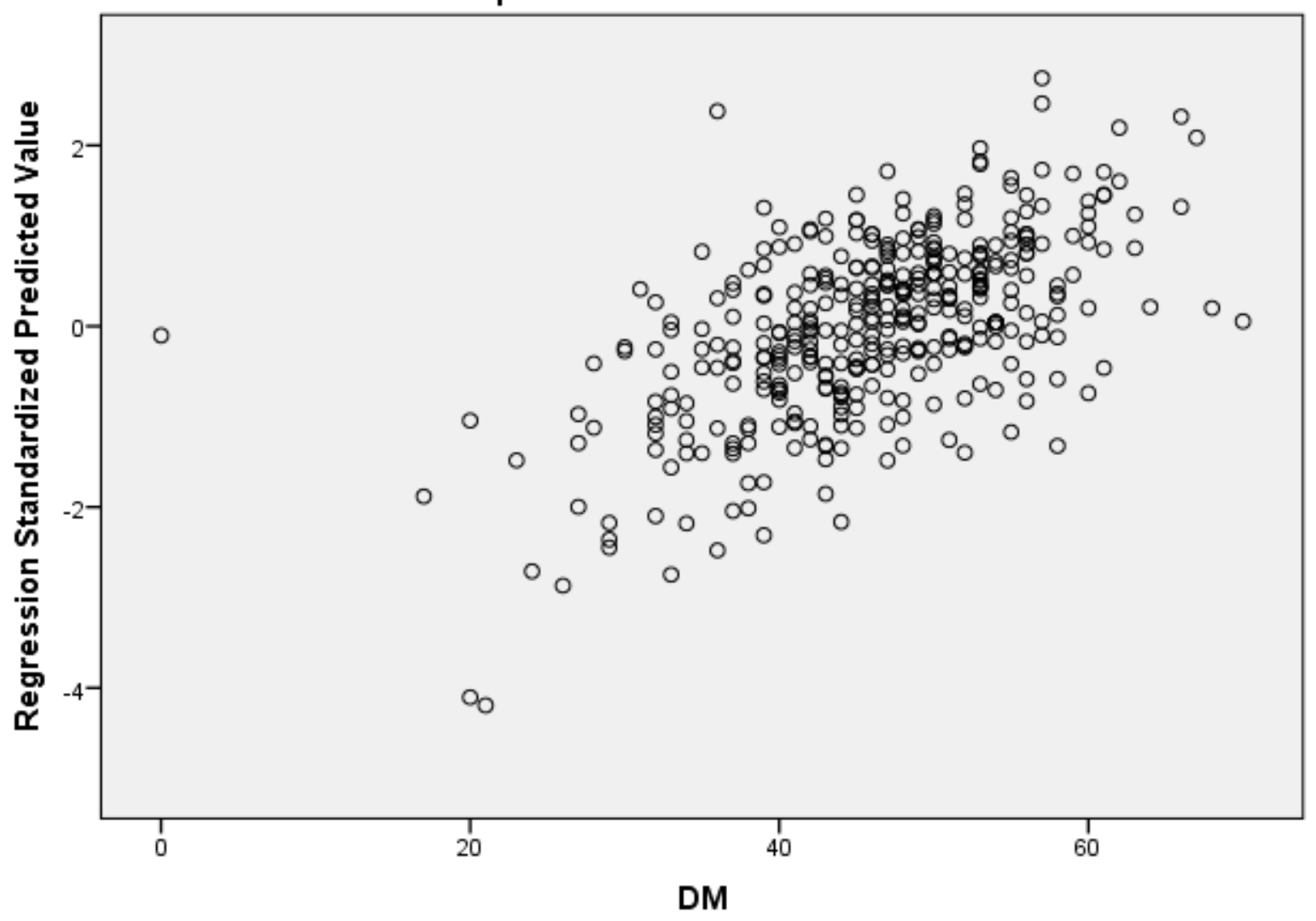

Figure 4: shows the linear variation of decision making with that of predicted variables.

The findings from the above tables and plots clearly indicate that the four dimensions cognitive ability, tolerance ego and decision making quantify the EI of the individual. Table 2 to 5 and figure 1 to 4 reveals the interdependence of predicted and dependent variable linearly. This result agrees with the study conducted by Nawal G Alghamdi (2017) Hypotheses 6: There is no significant relationship between the four dimensions namely: Cognitive ability, Tolerance, Ego and Decision-making quantifying EI. 
Table 6: To show Pearson Correlation between the four dimensions of EI

\begin{tabular}{|c|c|c|c|c|c|}
\hline Variables & $\mathrm{N}$ & Mean & S. D & $\begin{array}{l}\text { Pearson } \\
\text { Correlation }\end{array}$ & $\begin{array}{ll}\text { Level } & \text { of } \\
\text { significance }\end{array}$ \\
\hline \multirow{2}{*}{$\begin{array}{l}\text { Cognitive ability } \\
\text { vs Tolerance }\end{array}$} & \multirow[t]{2}{*}{379} & 49.69 & 8.31 & \multirow{2}{*}{$0.383 * *$} & \multirow{2}{*}{$<0.01$} \\
\hline & & 43.88 & 8.37 & & \\
\hline \multirow{2}{*}{$\begin{array}{l}\text { Cognitive ability } \\
\text { vs Ego }\end{array}$} & \multirow[t]{2}{*}{379} & 49.69 & 8.31 & \multirow{2}{*}{$0.310 * *$} & \multirow{2}{*}{$<0.01$} \\
\hline & & 39.34 & 9.40 & & \\
\hline \multirow{3}{*}{\begin{tabular}{lr}
\multicolumn{2}{l}{ Cognitive } \\
vs & Decility \\
making &
\end{tabular}} & \multirow[t]{3}{*}{379} & 49.69 & 8.31 & \multirow{3}{*}{$0.452 * *$} & \multirow{3}{*}{$<0.01$} \\
\hline & & & & & \\
\hline & & 45.96 & 9.08 & & \\
\hline \multirow[t]{2}{*}{ Tolerance vs Ego } & \multirow[t]{2}{*}{379} & 43.88 & 8.37 & \multirow[b]{2}{*}{$0.398 * *$} & \multirow[b]{2}{*}{$<0.01$} \\
\hline & & 39.34 & 9.40 & & \\
\hline \multirow{2}{*}{$\begin{array}{l}\text { Tolerance vs } \\
\text { Decision making }\end{array}$} & \multirow[t]{2}{*}{379} & 43.88 & 8.37 & \multirow{2}{*}{$0.402 * *$} & \multirow{2}{*}{$<0.01$} \\
\hline & & 45.86 & 9.08 & & \\
\hline \multirow{2}{*}{$\begin{array}{l}\text { Ego vs Decision } \\
\text { making }\end{array}$} & \multirow[t]{2}{*}{379} & 39.34 & 9.40 & \multirow{2}{*}{$0.464 * *$} & \multirow{2}{*}{$<0.01$} \\
\hline & & 45.86 & 9.08 & & \\
\hline
\end{tabular}

Pearson correlation values showing the interrelationship between the variables are significant at 0.01 level thus together they quantify the EI.

From the table 6 it is obvious that all the four dimensions are significantly related to one another and interestingly ego and decision making are strongly related indicating that individual's with strong ego dare not flexible with their decision. Cognitive ability and ego are fairly related indicating that it is not possible to generalize that the individuals with high cognitive ability are egoistic. Therefore, cognitive ability and ego are individual's trait. This result is similar to IGT (Iowa Gambling task) carried out in a study conducted by Toplak ME (2010).

\section{Discussion}

Maryam Meshkat, Reza Nejati (2017) conducted a study to determine gender differences in emotional intelligence and its components using The Bar-On Emotional Quotient Inventory to 455 undergraduate students doing English major from Allameh Tabatabaee University, Khatam University, and Shahid Rajaee Teacher Training University in Tehran. MANOVA showed that there is significant difference between male and female students with respect to emotional intelligence though females scored better with respect to empathy, self-awareness, interpersonal relationship and self-regard. Another study by Rooy, Alonso \& Viswesvaran (2004) explored that female exhibited superior level of emotional intelligence. The above studies support the result of is based the present study indicating significant difference between male and female population with respect to tolerance 
component of EI. Nawal G Alghamdi (2017) carried out a study on personality traits as indicators of EI among the university teachers working as student advisors. The sample is comprised of 100 student advisors (male $=50$; female $=50$ ) in the age group $20-40$ years. Schutte Emotional Intelligence Scale (SEIS) and Big Five Inventory (BFI) were used to measure emotional intelligence (EI) and personality traits. Regression analysis revealed that three personality traits, extraversion, agreeableness, and openness to experience, emerged as significant predictors of EI. The findings also revealed that conscientiousness and neuroticism have no impact on EI. Purificacion Checa (2019) carried out a study on hot (emotional) and cool (neutral) cognitive tasks in two groups: one high and one low on EI, in order to determine the role of EI on cognitive processes. The results showed that the groups with low and high EI showed significant relationship with cool task while the high EI group was better at carrying out the hot task. This showed that EI has an impact on cognitive process. David Tzuriel (2014) conducted a study in Israel to find the relationship between Ego identity of EI with Cognitive ability. cognitive modifiability among 238 adolescents in the age group 16 to 18 years. They were tested on three dynamic assessment measures (Set Variations II, Complex figure and Organizer from Learning Propensity Assessment Device) and Adolescent Ego Identity Scale (AEIS). Canonical correlation results were found to be positive ( $\mathrm{r}=0.40$, $\mathrm{p}<0.05)$ for Ego and Cognitive ability and $(\mathrm{r}=0.39, \mathrm{p}<0.05)$ for Cognitive modifiability. The results are found to be similar to above research finding indicating that individuals with high Cognitive ability tend to resolve conflicts better leading to high EI index. Beatrice Rammstedt (2018) conducted a study in Germany on a sample $N=365$ to find the relationship between Cognitive ability and Personality in which tolerance as one of the indices, the research findings showed a positive relationship between the two showing a clear evidence that individuals with high cognitive ability know to deal with problems patiently. Toplak ME (2010) reviewed 43 research studies that deals with finding the relationship between Decision making and Cognition using Iowa gambling task IGT. It was found that a majority of the studies showed significant correlation between IGT performance and cognitive abilities. Therefore, many research studies discussed so far are in support of the research findings of the present research.

\section{Conclusions}

Emotional Intelligence is considered as one of the important personality traits of individuals to sustain as global innovators in the $21^{\text {st }}$ century. Therefore, the school and college educators, policy makers, should necessarily implement strategies to help their students to evolve as global innovators. This could be achieved only through teachers. The private organizations instead of viewing "Education" as a commodity through which they are benefited monetarily, should change their attitude and work with the government closely improving the quality of teachers not only in knowledge building of the society but also a emotionally stable society. Therefore, a society comprising stronger emotionally intelligent people can flourish into a society of innovators in all avenues of indices necessary for the growth of sustainable, innovative human capital.

\section{References}

[1] A.Megias et al (2017, The relationship between Trait Psychopathy and Emotional Intelligence : a meta Analytical review, Neuroscience and Behavioural Review.

[2] Bar On et al (2003), Emotional quotient Inventory, Resource Reports, Chris Devan Publication. 
[3] Beatrice Rammstedt (2018), Relationship between Personality and Cognitive ability: A Facet level analysis, Journal of Intelligence,

[4] Bechara A. (2004). The role of emotion in decision-making: evidence from neurological patients with orbitofrontal damage. Brain Cognition. 55, 30-40 10.1016/j.bandc.2003.04.001 [PubMed] [CrossRef] [Google Scholar]

[5] Damasio, A. Descartes (1994)' Error: Emotion, Reason and the Human Brain; Gosset/Putnam: New York, NY, USA, 1994.

[6] Eric Bern (1950), Transactional Analysis, https://BusinessBalls.com

[7] Faltas (2017), The three theories of Emotional Intelligence Explained, https:// positive Psychology.com.

[8] Flanker (Eriksen and Eriksen 1774).. "Effects of noise letters upon identification of a target letter in a non- search task". Perception and Psychophysics. 16: 143 149. doi: $10.3758 / \mathrm{bf03203267.}$

[9] George J (2000), Emotions and Leadership: The role of Emotional Intelligence, Human Relations Vol 53 (8), Sage Publications.

[10] George, J. M. \& Bettenhausen, K. (1990). Understanding prosocial behaviour, sales performance, and turnover: A group-level analysis in a service context. Journal of Applied Psychology, 75, 698-709. doi:10.1037/0021-9010.75.6.698

[11] George, J.M. Leader positive mood and group performance: The case of customer service. Journal of Applied Social Psychology, 1995, 25, 778-94.

[12] Goleman (2002), The New Leaders: Transforming the Art of Leadership into the Science of Results, sphere publication.

[13] Goleman, D. Emotional intelligence. New York: Bantam Books, 1995.

[14] Goleman, D.; Boyatzis, R.; Rhee, K. (2001) Clustering Competence in Emotional Intelligence: Insights from the Emotional Competence Inventory (ECI). In Handbook of Emotional Intelligence. Bar-On, R., Parker, J., Eds.; Jossey-Bass: San Francisco, CA, USA.

[15] Gutiérrez-Cobo, M. J., Cabello, R. \& Fernández-Berrocal, P. (2017) The three models of emotional intelligence and performance in a hot and cool go/no-go task in undergraduate students. Front. Behav. Neurosci. 11, 1-13.

[16] Joseph, D. L. \& Newman, D. A. (2010) Emotional intelligence: an integrative metaanalysis and cascading model. J. Appl. Psychol. 95, 54-78 (2010).

[17] Kristine Gill Belarmino (2018), A Good Teacher Inside out of a Classroom, Asia Pacific journal of Psychology

[18] Maryam Meshkat, Reza Nejati (2017), Does Emotional Intelligence depend on gender? A study on undergraduate English Majors of three Iranian Universities, Sage open Journal, vol 7 issue 3 https://doi.org/10.1177/2158244017725796.

[19] Mayer J.D , Salovy P, (1990), Emotional Intelligence, Cognition, vol 9, 185-211.

[20] Nawal G Alghamdi (2017). Personality traits as a predictor of Emotional Intelligence among University teachers as Advisors, Educational research international volume. https://doi.org/10.1155/2017/9282565.

[21] Purifaccion et al (2019), Neuro Cognitive and Temperamental systems of Selfregulation on early adolescents social and academic outcomes, Mind and Brain journal

[22] Salovey, P. \& Mayer, J. D, (1990). Emotional Intelligence. Imagination, Cognition, and Personality, 9, 185-211. 
[23] Sternberg R.J (1997), The concept of intelligence and its role in lifelong learning and success, American Psychologist.

[24] Sternberg R.J. The concept of intelligence and its role in lifelong learning and success. Am.Psychol. 1997;52:1030-1037. 10i: 1037/0003066X.52.10.1030. [CrossRef] [Google Scholar]

[25] Tzuriel D (2014) Cognitive Modifiability and Ego Identity among Adolescents. J Psychol Psychother 4: 147. doi: 10.4172/2161-0487.1000147.

[26] Van Rooy, D., Alonso, A. and Viswesvaran, C. (2004) Group Differences in Emotional Intelligence Scores: Theoretical and Practical Implications. Personality and Individual Differences, 38, 689-700. http://dx.doi.org/10.1016/j.paid.2004.05.023.

[27] Webb, C. A., DelDonno, S., and Killgore, W. D. S. (2014). The role of cognitive versus emotional intelligence in Iowa Gambling Task performance: what's emotion go to do with it? Intelligence 44, 112-119. doi: 10.1016/j.intell.2014.03.008. 